\section{$\underset{\substack{\text { hommes } \\ \text { \& migrations }}}{ }$}

\section{Hommes \& migrations}

Revue française de référence sur les dynamiques

migratoires

\section{$1280 \mid 2009$}

Les Turcs en France : quels ancrages?

\title{
Après l'océan
}

Film français d'Eliane de Latour

\section{André Videau}

\section{(2) OpenEdition \\ 1 Journals}

Édition électronique

URL : http://journals.openedition.org/hommesmigrations/331

DOI : 10.4000/hommesmigrations.331

ISSN : 2262-3353

Éditeur

Musée national de l'histoire de l'immigration

\section{Édition imprimée}

Date de publication : 1 juillet 2009

Pagination : 167-168

ISSN : 1142-852X

\section{Référence électronique}

André Videau, «Après l'océan », Hommes \& migrations [En ligne], 1280 | 2009, mis en ligne le 29 mai 2013, consulté le 22 septembre 2020. URL : http://journals.openedition.org/hommesmigrations/331 ; DOI : https://doi.org/10.4000/hommesmigrations.331

Ce document a été généré automatiquement le 22 septembre 2020.

Tous droits réservés 


\title{
Après l'océan
}

\author{
Film français d'Eliane de Latour
}

\section{André Videau}

D'abord anthropologue et directrice de recherche au CNRS, Eliane de Latour, passionnée par l'Afrique, s'est orientée vers le cinéma. Elle a réalisé plusieurs documentaires (Tidjan ou les voies d'Allah (1989), Si bleu, si calme... (1996)), mais c'est avec Bronx-Barbès (2000) (voir H\&M, $\mathrm{n}^{\circ} 1229$, janvier-février 2001) qu'elle accède à la notoriété. Avec les aventures de Toussaint et de Nixon, deux intrépides adolescents du ghetto d'une cité portuaire aux couleurs d'Abidjan, la réalisatrice, qui porte un regard aigu sur des réalités trop souvent ignorées, une habitude qu'elle a acquise dans la pratique du documentaire, a su toucher un public plus large.

2 Après l'océan, sa nouvelle fiction, s'inscrit dans la même démarche, avec des résultats peut-être moins probants. L'intérêt fusionnel que la réalisatrice porte à l'Afrique devait tout naturellement l'amener à se confronter aux problèmes de l'émigration. Cependant, son tempérament, comme ses convictions et ses expériences, ne va pas l'entraîner vers le témoignage paupériste, moralisateur, militant, qui place le pauvre candidat à l'exil, travailleur analphabète et aux abois, au cœur d'une chaîne d'exploitations, de déconvenues, de brimades, qui l'aliène dès le départ à un réseau clandestin de recrutement, de transport, de logement, d'embauche. Avant que s'ensuivent les conflits identitaires, les difficultés d'intégration, le racisme, la xénophobie, et toutes les séquelles du corps et de l'âme. D'autres l'ont fait, parfois de façon irréprochable.

3 La spécificité d'Eliane de Latour est de traiter ses personnages de l'intérieur, pour mieux les libérer des contingences stéréotypées, de laisser les coudées franches à leurs gestes et libre cours à leurs paroles et à leurs discours, au risque de permettre aux désordres de la vie de s'installer dans le film, dans une apparente pagaille.

4 Il ne faut pas non plus se fier à un titre restrictif qui pourrait orienter vers un constat, une sorte de bilan de la situation de l'émigré africain dès lors qu'il a franchi l'obstacle majeur pour sa mentalité de terrien : le franchissement de la frontière maritime entre les continents antagonistes, le noir et le blanc, le chaud et le froid, le pauvre et le riche. Il n'y a pas d'aller simple pour un pays de cocagne, ni de retour obligé vers l'enfer. 
5 Commençons par le commencement. Dans une Afrique vraie de vraie, c'est-à-dire débarrassée des poncifs coloniaux ou néocoloniaux, Otho et Shad (Djédjé Apali et Fraser James) sont deux amis oisifs qui veulent aller tenter leur chance en Europe. Rêves d'argent et d'amours faciles que partagent leurs potes Tétanos ou Baudelaire (la fantaisie des surnoms fait partie du pittoresque : dans Bronx-Barbès, on rencontrait déjà Pablo Escobar, Tarek Aziz et même Chirac, compagnons des héros Toussaint et Nixon). Les destins des héros vont diverger. Selon les codes en vigueur, l'un réussit, l'autre pas. Le guerrier ne peut pas revenir sans gibier, mais la vitalité des caractères, commela truculence des dialogues "dans un français renversant" et l'implication des comparses (Kad Mérad, Malik Zidi, Sarah Martins, Marie-Josée Croze, Lucien Jean-Baptiste, Agnès Soral), fait que "chacun dans son chacun", qu'il soit dans l'acceptation ou le refus, n'apparaît en définitive ni comme modèle ni comme maudit. La réussite économique se construira dans la liberté, et vice-versa, comme la robe de mariée de Pélagie confectionnée par Billy, le couturier local, avec un génie créatif indigène et attribuée à Jean-Paul Gaultier !

6 Malgré les plaisirs de la démonstration, le spectateur risque de perdre pied. Il devra se laisser porter. 